\title{
W POSZUKIWANIU POCZATTKÓW ORAZ PRÓB ZROZUMIENIA „ZACHOWAŃ SYMBOLICZNYCH”. ZARYS PROBLEMATYKI
}

\author{
IN SEARCH OF THE BEGINNINGS \\ AND TRIALS TO UNDERSTAND \\ "SYMBOLIC BEHAVIOR". OUTLINE OF THE PROBLEM
}

\section{Bożena Józefów-Czerwińska}

https://orcid.org/0000-0001-6564-1755

Akademia Finansów i Biznesu Vistula

Filia Akademii im. Aleksandra Gieysztora, Wydział Humanistyczny

b.jozefow-czerwinska@vistula.edu.pl

\begin{abstract}
In academic literature there is a whole range of hypotheses relating to the genesis of the symbolic behavior, which are usually also associated with the beginnings of the development of spirituality. In the nineteenth century, the considerations conducted in this area were often influenced by negative stereotypes (relating, among others, to hunter-gatherers), which were later deconstructed.

Although the discussion on this subject has been ongoing since the nineteenth century, even in the light of research and achievements of the modern science, the problem of the origins of symbolic behavior has still not been unequivocally resolved. However, it is assumed that they should be attributed primarily to the changes that were initiated in our ancestors from the Homo Sapiens family. In recent years, however, some ethologists and primatologists believe that the genesis of symbolic behavior should be sought in the animal world. I devote my article to this diversified subject matter.
\end{abstract}

KEY WORDS: symbolic behavior, symbolic threshold, genesis of symbolic behavior, Palaeolithic artists

W badaniach archeologicznych, w próbach interpretacji zjawisk, obiektów oraz artefaktów, które mogą być powiązane z wierzeniami i religijnością badanych społeczności, napotykano na wiele problemów. W szczególności dotyczy to ludów paleolitycznych i prób zrozumienia motywacji twórców kreujących dzieła ówczesnej 
sztuki, co odnosi się m.in. również do ich doświadczeń, koncepcji, symboli i idei konotowanych np. $\mathrm{z}$ ich wytworami.

Motywy figuralne mogły być i były oczywiście powiązane z realnym dla twórców światem (z ich środowiskiem). Ale należy pamiętać, że w dawnej sztuce spotykamy się również, a może przede wszystkim z reprezentacjami „symbolicznymi”, powiązanymi z interakcją symboliczną, z doświadczeniem liminalnym, z intersubiektywną „przestrzenią”, w której powstają kulturowe światy. Te zjawiska, jak podkreślali semiotycy szkoły postmodernistycznej, są dla nas niemożliwe do poznania (Henshilwood, d'Errico, 2011; Nixon, 2010, s. 293).

Badaczom podejmującym się próby analiz ,zachowań symbolicznych”, wierzeń czy szerzej zjawisk religijnych w powiązaniu np. do sfer/obiektów kultu nie ułatwia to, że od badanych dzieli nas ogromny dystans czasu oraz bariery wynikające ze skrajnych różnic kulturowych (Maruszewski, 1996). Jednak zdaniem niektórych badaczy cenne są w próbach takich analiz źródła etnograficzne, odwołujące się nawet do współczesnych łowców-zbieraczy. Ich poznanie może nie tylko rozszerzyć wyobraźnię badawczą, ale i pozwolić na rozwijanie studiów powiązanych z tą tematyką (Lewis-Williams, 1981; Boyer, 2001; Boyer, Bergstrom, 2008, s. 111-130). Mimo tego problem genezy zachowań symbolicznych i podążających za nimi konceptualizacji, w odniesieniu do prób poznania rozwoju duchowości oraz wierzeń (symbolic threshold), pozostaje aktualny. Zazwyczaj łączymy te zjawiska z Homo sapiens, który wskutek rozwoju mózgu i zdolności umysłowych stał się istotą zdolną do wyższych konceptualizacji (co w rozwiniętej formie rozwoju duchowości, mającej miejsce wiele tysięcy dekad później, doprowadziło do powstania m.in. koncepcji odnoszących się do transcendencji; wiary w życie pozagrobowe; w Boga/ów wraz z rozwiniętą sferą religijnych rytuałów). W świetle niektórych badaczy przyjmuje się, że początków tego wyjątkowego okresu transformacji, mającego największe konsekwencje dla nas, potomków Homo sapiens, należy szukać gdzieś około 100 tys. lat temu (o czym miałyby świadczyć artefakty odkryte w południowoafrykańskiej jaskini Blombos oraz w obrębie schroniska skalnego Diepkloof). Współcześnie jednakże wciąż trwa dyskusja, czy odkrywane na wytworach ludzkich motywy nie były tylko dekoracją, bez symbolicznych konotacji (Tylén, Fusaroli, Rojo, Heimann, Fay, Johannsen, Riede, Lombard, 2020, s. 4578-4584).

Niemniej pogląd, że tylko Homo sapiens był zdolny do rozwoju duchowości i z nią powiązanych zachowań rytualnych, został stopniowo obalony wraz z kolejnymi odkryciami świadectw zachowań symbolicznych - neandertalczyka. Wpłynęło to na przeświadczenie, że genezy takich transformacji należy poszukiwać przede wszystkim w rozwoju Homo sapiens (dopuszczając z czasem możliwość, że również Homo neanderthalis był zdolny do zachowań symbolicznych).

W ostatnich latach w debatach naukowych pojawia się jednakże pytanie, czy genezy takich zachowań, które odnoszą się do wyższych uczuć, w tym zrytualizowanych działań symbolicznych, należy doszukiwać się tylko u hominidów Homo sapiens i Homo neanderthalis, czy też mogą być one efektem wcześniejszych etapów ewolucji? Pojawiły się również hipotezy, wedle których początków zachowań zrytu- 
alizowanych - wykraczających poza sferę popędów, instynktów - należy być może poszukiwać także w świecie zwierząt.

\section{STOSUNEK DO SPOŁECZNOŚCI RDZENNYCH A INTERPRETACJA ODKRYĆ PALEOLITYCZNYCH W XIX W.}

W perspektywie rozwoju badań na przeszkodzie w interpretacji źródeł powiązanych z duchowością niejednokrotnie stawały kulturowe uprzedzenia, negatywne stereotypy i etnocentryczne postawy. W tym kontekście warto zwrócić uwagę na kilka wątków związanych z historią m.in. badań sztuki paleolitycznej.

Zanim doszło do wielkich odkryć sanktuariów paleolitycznych (na terenach m.in. Hiszpanii czy Francji) w XIX w. niejednokrotnie postrzegano wytwory paleolitycznej sztuki w kategorii prymitywnych. W ówczesnej nauce pokutował pogląd etnocentryczny, w myśl którego społeczności pierwotne co najwyżej posiadały zalążki sztuki, która w rozwiniętej cywilizacji wyewoluowała do sztuki tzw. wysokiej (Palacio-Pérez, 2010, s. 1-14). Nie od razu też łączono takie wytwory z głębszymi koncepcjami, symbolami czy szerzej z wierzeniami, religijnymi praktykami. Dopiero z czasem narodziły się w dyskursach badawczych takie idee i pojęcia, jak np. „sanktuarium paleolityczne”, „sztuka inicjacji” , „obrazy totemiczne” i „szamańskie symbole”, które warunkowały w zmodyfikowanych formach interpretację sztuki paleolitycznej, co ma miejsce do chwili obecnej ${ }^{1}$.

Jednocześnie należy podkreślić, że uproszczonym, ewolucjonistycznym sposobom percepcji społeczności, które żyły na najniższym stadium rozwoju (według ówczesnych klasyfikacji, co miało dotyczyć także wierzeń), sprzeciwiał się m.in. Edward B. Tylor oraz inni badacze (uwzględniający dane etnograficzne). Postulowali oni, aby badać różne ,zalążki wierzeń”, co doprowadziło do powstania koncepcji animizmu (Tylor, 1867, s. 707), magii (Frazer, 1890), totemizmu (McLennan, 1869) i in. (Szyjewski, 2008). Z czasem stały się one istotne dla badaczy wykraczających poza etnocentryzm i podejmujących się prób pogłębionych analiz tych zjawisk.

Nazbyt uproszczonym poglądom niektórych ewolucjonistów już pod koniec XIX w. oraz na początku XX w. coraz częściej przeciwstawiał się większy krąg myślicieli, którzy twierdzili, że wytwory sztuki łowców-zbieraczy oraz wytwory sztuki paleolitycznej należy łączyć z ich wierzeniami. Do klasyków takiego podejścia zalicza się Ernsta Grosse (Grosse, 1894), Moritza Hoernesa (Hoernes, 1909) czy m.in. szwedzkiego badacza Yrjö Hirna (Hirn, 1900), którzy czerpali z etnograficznych źródeł.

\footnotetext{
${ }^{1}$ W opinii Eduardo Palacio-Pereza, który poddał badaniom m.in. negatywne stereotypy XIX w. względem paleolitycznych odkryć na tle przemian zachodzących w sposobach ich interpretacji, to „,dopiero od lat 60. XX w. ukorzeniła się i rozwijała idea, że odkrycia paleolitycznej sztuki jaskiniowej są ściśle powiązane z ,konceptualnym odkryciem” symbolicznego i religijnego świata paleolitycznych twórców” (Palacio-Pérez, 2010, s. 11). W konsekwencji pojawiły się przełomowe prace, np. André Leroi-Gourhana (Leroi-Gourhan, 1965, 1966) i in.
} 
Hirn postulował przykładowo, aby zwrócić uwagę na to, że sztuka ludów „,prymitywnych" mogła pełnić funkcję użytkową. Twierdził, że taka sztuka rzadko kiedy jest wolna i bezinteresowna; ma ogólnie użyteczną lub rzekomą przydatność i często jest nawet koniecznością życia. Przy czym szczególną uwagę przywiązywał do jej aspektu magicznego, dowodząc, że przez akt twórczy chciano wywrzeć wpływ na byty nadprzyrodzone (Hirn, 1900, s. 12). Henry Balfour (Balfour, 1893) i Alfred Haddon uważali natomiast, że abstrakcyjne motywy znane z niefiguratywnej sztuki mogły wyewoluować z realistycznych przedstawień (Haddon, 1895). Niewątpliwie zaś wyjątkowymi jak na XIX w. poglądami zapisał się w historii interesujących nas badań William Martin Conway, który w szkicu archeologicznym, opublikowanym w 1891 roku twierdził, że wytwory sztuki to duchowe i intelektualne produkty ludzkiego umysłu, które są różne w określonych czasach i miejscach. Ponadto uważał, że człowiek paleolityczny posiadał myślenie religijne, twierdząc, że sztuka i religia powstają we wspólnej atmosferze, wyzwalając podobne bądź takie same emocje (Conway, 1891, s. 9, 31; Palacio-Pérez, 2010, s. 1-14).

Należy też wspomnieć o poglądach Salomona Reinacha, który podążał tropem m.in. McLennana. Łączył on sztukę paleolityczną z magiczno-religijnymi kontekstami, przypisując ,jaskiniowcom” dobrze rozwiniętą religijność i spekulując, że być może postaci zwierzęce, tak częste w ich sztuce, są dowodem pewnego rodzaju totemizmu. Jednocześnie podkreślił, że przesadą byłoby twierdzenie, że magia jest jedynym źródłem sztuki, zaprzeczając różnym formom naśladownictwa, chęci zdobienia i twórczej kreatywności artysty czy społecznej potrzeby wyrażania i komunikowania myśli (Reinach, 1899, s. 478). Niemniej odkrycie wizerunków jaskiniowych na terenach Francji i Hiszpanii oraz uzupełniające odkrycia rzeźbionych i grawerowanych artefaktów w jego opinii wydaje się wskazywać, ,że wielki wzrost sztuki w epoce reniferów był związany z rozwojem magii” (Reinach, 1903, s. 266; Palacio-Pérez, 2010, s. 1-14).

Zasygnalizowano już, że w próbach zrozumienia sztuki paleolitycznej oraz łowców-zbieraczy na przeszkodzie stanął stosunek m.in. Europejczyków do społeczności rdzennych. Praktycznie od początku wielkich odkryć geograficznych toczyły się dyskusje dotyczące natury spotykanych na nowych lądach ludów. Powracało nawet pytanie, czy są to ludzie? A jeśli tak należy ich postrzegać, to czy należy ich chrzcić, edukować, czy też ze względu na ich ,prymitywizm” wykorzystać - niczym udomowione zwierzęta - do niewolniczej pracy itd.? ${ }^{2}$. Te dylematy przetrwały do XIX w., a miejscami znacznie dłużej.

Niemniej w XIX w. rozwijano też pseudonaukowe koncepcje rasowe, które w okresie II wojny światowej doprowadziły do eksterminacji bądź zniewolenia milionów osób (Fredrickson, 1988). Zanim doszło do tych tragicznych wydarzeń, rozwi-

\footnotetext{
2 Najczęściej dla rdzennych ludów zderzenie z kulturą Europejczyków na dłuższą metę kończyło się tragicznie, o czym m.in. pisał C. Lévi-Strauss, przytaczając historię tzw. Hispanioli i podkreślając, że gdy odkryto te ziemie, zamieszkiwało je ok. 100 tys. ludności, a po upływie wieku pozostało z nich jedynie dwustu ludzi.
} 
jała się też eugenika (najpierw w USA), a następnie w Europie (Zaremba, 2011). Jej celem było m.in. wyeliminowanie lub pozbawienie możliwości reprodukcji tych, którzy według dzisiejszej terminologii mieli obciążenia genetyczne bądź też byli „mniej pożądani” ze względów rasowych (Carlson, 2001).

W początkach XX w. etnocentrycznemu i pejoratywnemu stosunkowi do żyjących społeczności rdzennych przeciwstawiali się badacze głoszący koncepcję relatywizmu kulturowego. W myśl jej dowodzono, że nie ma kultur lepszych czy gorszych, jest tylko ogromna różnorodność kulturowa. Obserwowane zaś różnice w zachowaniu ludzkim nie są determinowane wrodzonymi czynnikami biologicznymi, ale są wynikiem różnic kulturowych, nabytych w trakcie wychowania w danym społeczeństwie (Boas, 1911).

Minęło jednak wiele lat, a nawet dekad zanim doszło do poszanowania i docenienia kulturowej różnorodności. Dobrze to zjawisko obrazuje stosunek rządu Australii do ludności rdzennej zamieszkującej ten kontynent. Warto przypomnieć, że jeszcze w początkach lat 60 . XX w. Aborygeni byli wpisani w atlasy fauny i flory Australii (i opisywani jako zwierzęta). Ich dzieci były porywane, trwale rozdzielane z rodzinami, a następnie w sierocińcach poddawane przymusowej ,asymilacji” (lost generation). W latach 80. XX w. przyznano im prawa wyborcze, a dopiero w 2001 roku powołano Radę Pojednania (Council for Aboriginal Reconciliation). W 2009 roku Kevin Rudd - ówczesny premier Australii - przeprosił Aborygenów za krzywdy jakich doświadczyli (Sutton, 2009).

Jednocześnie $\mathrm{w}$ ostatnich dziesięcioleciach $\mathrm{w}$ środowisku nauki wzrosło zainteresowanie duchowością, wierzeniami i sztuką m.in. Aborygenów, które to wcześniej, zwłaszcza w kulturze popularnej, zazwyczaj postrzegano wciąż w kategoriach „zjawisk prymitywnych". Poznawano m.in. koncepcje wierzeniowe (w tym mity kosmogoniczne, totemiczne i in.); stosunek do krajobrazu, miejsc; motywacje i doświadczenia twórców sztuki, jak i inne wytwory niematerialnego dziedzictwa tych ludów i ich kultur. Spotkano się z niezwykle złożonymi koncepcjami, konceptualizacjami, których próby zrozumienia i poznawania trwają dotąd (Stanner, 1966).

Wraz z rosnącą świadomością badawczą nastąpiły zmiany widoczne nie tylko w stosunku do rdzennych społeczności, ale i w sposobach interpretacji i percepcji odkryć paleolitycznych łowców-zbieraczy. Dzięki temu konstruowano m.in. nowe pytania badawcze, co w konsekwencji doprowadziło z czasem do pogłębionych analiz, w tym rozwoju nowych ujęć metodologicznych (Sauvet, Layton, Lenssen-Erz, Taçon, Włodarczyk, 2009).

\section{ZWROT KU NARRACYJNOŚCI ORAZ INTERDYSCYPLINARNOŚCI}

W ujęciu Clifforda Geertza duchowość i religia definiowane są jako system symboli, który działa w celu ustanowienia silnych, wszechobecnych i długotrwałych postaw, uczuć i motywacji (Geertz, 2002, s. 61-82). W tej perspektywie dostrzeżono m.in. relacje istniejące między umysłem, doświadczeniem społecznym a językiem 
(Pütz, Verspoor, 2000). Ponadto zwrócono uwagę na to, że np. reprezentacje mentalne przedmiotów (obiektów) nie są samodzielnymi jednostkami, powstają wraz z myślami w wyniku przyczynowej interakcji z przedmiotem (obiektem), ale również przez percepcję przedmiotu/obiektu (Ciok, 2010, s. 45).

Ikonograficzne przedstawienia można łączyć nie tylko z daną reprezentacją np. powstającą w umyśle człowieka, ale i można je postrzegać w kategoriach zjawisk wpisanych w proces komunikacji. Czerpiąc z poglądów Karla Ottona Apla (filozofia pierwsza naszych czasów), można przyjąć, że społeczeństwo, jednostkę winniśmy oglądać właśnie przez pryzmat procesu komunikacji, dzięki któremu nie tylko możemy zrozumieć człowieka, ale też dostrzec, że Homo sapiens „,staje się człowiekiem poprzez i w procesie komunikacji” (Kulczycki, 2012, s. 56), co m.in. jest łączone z procesem przekazywania wiedzy (adaptacyjny model rozwoju kultury).

Badania ikonograficzne ukierunkowane są także na próby odtworzenia utraconego już doświadczenia kulturowego. Oczywiście między badaczem a „,badanymi” istnieją bariery nie tylko kulturowe, ale przede wszystkim poznawcze, które odnoszą się m.in. do różnych sposobów percepcji świata, co już zostało zasygnalizowane. Objawiają się one w obrębie konfiguracji wzorów, kodów kulturowych, w strategiach, motywacjach, sposobach wartościowania, procesach symbolizacji, symbolach, których rozpoznanie wymaga nie tylko ich dostrzeżenia czy nie tyle próby zrozumienia ich jednoznacznych znaczeń, lecz przede wszystkim pogłębionej nad nimi refleksji odnoszącej się do doświadczenia.

Warto nadmienić, że początkowo w archeologii (po tzw. zwrocie etnograficznym) w próbach zrozumienia np. paleolitycznych przedstawień naskalnych czerpano wybiórczo m.in. z informacji odnoszących się do zróżnicowanych żyjących społeczności łowców-zbieraczy. Brakowało też rozwiniętej metodologii badań pozwalającej unikać kolejnych uproszczeń i generalizacji ${ }^{3}$.

Dlatego we współczesnych dyskursach badacz próbuje przyjąć rolę uczestnika, starając się odtworzyć wielowymiarowe konteksty, poznając złożone znaczenia np. dzieła sztuki, które kiedyś było zrozumiałe dla ich twórców (Kilijanek, 2009, s. 192). Ich celem staje się zbudowanie narracji, nie zaś konstruowanie „wielkich prawd”. Jak twierdziła Kristian Hanstrup, nie ma bowiem „fundamentalnej, referencyjnej, realistycznie rozumianej prawdy, której cechą konstytutywną jest zwrotność refleksji ${ }^{4}$ uzależnienie wiedzy od samego wiedzącego [...]. Teoria antropologiczna ma ekspresyjny, a nie denotacyjny charakter" (Hanstrup, 2008, s. 194; Barański, 2010, s. 94).

W związku z powyższym coraz częściej poszukiwane są odpowiedzi na przykładowe pytania: Jak żyła dana społeczność?; Jak ludzie mogli doświadczać zjawisk świata w danym miejscu?; Co mogło wpływać na takie, a nie inne motywacje?... na

\footnotetext{
${ }^{3}$ Przeglądu takich problemów badawczych, w tym omówienia rosnącej krytyki takiego sposobu czerpania ze źródeł etnograficznych dokonała m.in. María Cruz Berrocal (Berrocal, 2011, s. 1-20).

${ }^{4}$ Ewa Klekot w przypisie thumaczonej przez badaczkę monografii Kristin Hanstrup podkreśliła, że takie terminy, jak zwrotność, refleksywność i refleksyjność nie oddają do końca znaczenia reflexivity, proponując użycie terminu „Zwrotność refleksji” (Hanstrup, 2008, s. 74, przyp. 3).
} 
obierane strategie? - w tym poszukiwano np. przyczyn utrwalania bądź nieokreślonych reprezentacji symbolicznych itd.

W ich kontekście badacz konstruuje własną narrację, jedynie jedną z możliwych. Coraz częściej też w próbach zrozumienia, poznania i doświadczenia sięgano do możliwie pełnych i kontekstowo osadzonych etnograficznych źródeł. Takie podejście zaowocowało rozwojem badań prowadzonych m.in. nad paleolityczną sztuką naskalną (Blocker, 1994).

Przykładowo Lewis Williams, próbując zrozumieć doświadczenia i motywacje paleolitycznych twórców, poddawał badaniom nie tylko źródła archeologiczne, dane kognitywistyczne, ale także wyniki etnograficzne. W ich efekcie stwierdził np., że przynajmniej niektóre wizerunki naskalne mogły powstawać w odmiennych stanach świadomości, w transie, w którym pojawiała się tendencja umysłu do tworzenia geometrycznych kształtów (Lewis-Williams, Dowson, 1988, s. 201-244). Wyszedł z założenia, że skoro np. twórca górnopaleolityczny pod względem struktury mózgu, układu nerwowego nie różnił się raczej od współczesnego Homo sapiens, zatem stymulacje oddziałujące na ich mózg powinny być również podobne. W konsekwencji pozwoliło to przyjąć założenie, że twórca znajdujący się np. w odmiennym stanie świadomości mógłby kreować podobne obrazy/wizerunki (model neuropsychologiczny) (Lewis-Williams, 1991, s. 153)5.

Badając wizerunki naskalne w południowej Afryce, dotarł m.in. do przedstawicieli ludu San. Ustalił, że w sztuce naskalnej pojawiały się zróżnicowane motywy, a do jednych z najbardziej interesujących należały hybrydy ludzko-zwierzęce. Były one asocjowane przez miejscowych, przede wszystkim z tymi, którzy weszli w trans (a którzy to zyskiwali nadzwyczajną moc zwierząt, duchów, przodków), co odsyła nas do praktyk szamańskich ${ }^{6}$. Transu w tej społeczności doświadczali jednak nie tylko szamani, ale również inni, którzy np. przez taniec i śpiew łączyli się w aktach rytualnych z przodkami ${ }^{7}$. Odprawiano również w tej społeczności tańce i śpiewy uzdrawiające (gdy kobiety siedziały wokół ogniska i śpiewały, a mężczyźni tańczyli wokół nich) (Lewis-Williams, 2019, s. 4). Należy dodać, że z badań wielu żyjących rdzennych społeczności wynika, że takie praktyki religijne są ważne i wciąż odgrywają kluczową rolę m.in. w „symbolicznym uzdrawianiu” (co oczywiście nie jest kompatybilne ze współczesną medycyną dominującą w „zachodniej cywilizacji”) ${ }^{8}$.

W świetle wyników studiów prowadzonych nad sztuką naskalną w południowej Afryce Lewis Williams doszedł do wniosku, że powinna być ona postrzegana jako

${ }^{5} \mathrm{Z}$ czasem podkreślano, że np. motywy geometryczne mogły być utrwalane z powodu zróżnicowanych motywacji, odwołując się do całej palety możliwych znaczeń.

${ }^{6}$ Z hybrydami ludzko-zwierzęcymi spotykano się również w paleolitycznej sztuce, co poddał kompilacji Andrzej Szyjewski (Szyjewski, 2008, s. 224-227).

${ }^{7}$ Lewis Williams zarejestrował zachowanie kobiety z ludu San - Maghogh`ę, która jako jedna $\mathrm{z}$ ostatnich pamiętała rytualną praktykę tańca przed naskalnymi wizerunkami (Lewis-Williams, 2019, s. 4-11).

${ }^{8} \mathrm{O}$ znaczeniu symbolicznego uzdrawiania u społeczności rdzennych zamieszkujących obszar Kanady traktuje wiele pozycji w fachowej literaturze (Waldram, 1993, s. 345-362; Schiff, 2006, s. 48-69 i in.). 
element rytuałów religijnych, przy czym jednocześnie odwoływała się ona do koncepcji energii duchowej, do „odtworzenia duchowych lub nadprzyrodzonych mocy, których można dotknąć i z których ludzie mogliby czerpać siłę" (Lewis-Williams, 2006, s. 365).

Należy podkreślić, że społeczności rdzenne mają tendencję do przeżywania swojej obecności w świecie postrzeganym w kategoriach całości, ale też mistycznych więzi łączących wszelkie byty (Eliade, 1988, s. 27-29), które mogły wchodzić ze sobą w interakcję (B. Duran, E. Duran, 2002). Z ich duchowością korespondują silne relacje z naturą, w tym z obiektami, które są we współczesnej nauce postrzegane w kategoriach obiektów przyrody nieożywionej (przykładowo w transie szamanka może otrzymać wiedzę o mitach od kamienia, rośliny itp.) (Sams, Nitsch, 1991). Dla zachowania równowagi $\mathrm{w}$ świecie ważne są m.in. ceremonie religijne, święte pieśni, jak również miejsca ,szczególne”. Duży nacisk kładziony jest też na przestrzeganie prawa regulującego nie tylko życiem w społeczności, ale i z więziami ustanawianymi z naturą. Dlatego w takich miejscach odbywały się nie tylko zróżnicowane rytuały (np. szamańskie, związane z inicjacją osób doświadczających obrzędów przejścia i in. ${ }^{9}$ ), ale także mogły to być miejsca spotkań starszyzny (ludzi prawa) wyrokujących w sprawach wspólnoty ${ }^{10}$.

Jednocześnie zwykłe opisy ikonograficzne, badania reprezentacji m.in. z perspektywy holistycznej, wyjaśnienia budowy i znaczenia danego krajobrazu, konstruowanie i sprawdzanie dalszych hipotez (nie tylko w odniesieniu do dominującej aktualnie koncepcji szamanizmu) może zdaniem Maríi Cruz Berrocal w archeologii zaowocować dalszym rozwojem badań prowadzonych nad sztuką naskalną (Berrocal, 2011, s. 14-15).

\section{PROBLEMATYKA POCZĄTKÓW - „ZALĄŻKÓW DUCHOWOŚCI”}

We współczesnych próbach zrozumienia „zachowań symbolicznych”, w tym także „doświadczenia religijnego", podstawową kwestią jest przyjęcie założenia, że

${ }^{9}$ Sztuka naskalna występowała również w Kalifornii w społeczności Czumaszów i Jokutów. W świetle przeprowadzonych analiz niektóre z tych miejsc określano mianem kryjówki szamanów, co w szerszej skali odzwierciedla ich swoistą mapę. Traktowano je jako „miejsca mocy” przynależące do danych rodów szamańskich (zwłaszcza w centralno-południowej Kalifornii). Wiele z wizerunków naskalnych zawierało geometryczne, abstrakcyjne znaki, które łączono z wizjami szamanów, jak np. na stanowisku Echo Rock (w południowo-zachodniej Kalifornii). Również w tym przypadku łączono je zazwyczaj z przodkami oraz, podobnie jak w Tanzanii, odprawiane były przy nich rytuały (takie jak np. zaklinanie deszczu). W rytualnym działaniu wprowadzano się również w stany transowe m.in. poprzez pieśni i taniec, co także zaobserwowano w kontekście kolejnych odkryć. Dodatkowo niektóre z wizerunków naskalnych były powiązane m.in. z obrzędami przejścia i pozostawione na ścianach skał przez inicjowanych (Whitley, 2019, s. 38).

${ }_{10}$ Wizerunki naskalne, np. w Tanzanii, były konotowane z miejscami przynależącymi do danych klanów. W ich obrębie odbywały się zebrania starszyzny, np. w celu sprawowania sądów. Najważniejszą jednak kwestią była ich więź z przodkami, którzy, jak wierzono, mieli wpływ na losy żyjących. Przy nich odprawiano też rytuały zaklinania deszczu (a wówczas polewano wizerunki wodą, co łączono z napojeniem przodków) (Grzelczyk, 2019, s. 20-25). 
procesy z nimi powiązane znajdują odzwierciedlenie w aktywności mózgu człowieka (Saver, Rabin, 1997, s. 498). Takie podejście do badań „zachowań symbolicznych”, duchowości oraz zjawisk religijnych niewątpliwie uzupełniają wyniki analiz prowadzonych w ramach tzw. nowego naturalizmu. Wraz z rozwojem nowych technologii (w tym m.in. pozwalających zbadać aktywność mózgu człowieka w trakcie przeżywanych doświadczeń religijnych, takich jak np. medytacja, kontemplacja i in.) pozyskano wiele istotnych ustaleń badawczych ${ }^{11}$.

W nowym naturalizmie pojawiają się dążenia do naturalistycznego wyjaśnienia m.in. zjawisk powiązanych $\mathrm{z}$ religią, przy czym jednocześnie czerpano z koncepcji wypracowanych w ramach psychologii ewolucyjnej nauk przyrodniczych, ale przede wszystkim z kognitywizmu i neurobiologii. W tym ujęciu, co podkreślił Sławomir Sztajer, teorie, które odwołują się np. do religii, „nie mają charakteru spekulatywnego, lecz muszą sprostać standardowym procedurom sprawdzania hipotez w naukach empirycznych" (Sztajer, 2012, s. 97).

Jeśli zaś chodzi o badania dawnych hominidów, to według kognitywisty Włodzisława Ducha, chociaż paleoantropologia w ostatnich latach korzysta z różnych wyrafinowanych metod pozwalających np. na komputerową analizę czaszek i kości oraz współpracuje z genetykami, jak również z biologami molekularnymi, wciąż pozostaje wiele pytań i kontrowersji m.in. z tego powodu, że „,dostępny materiał kopalniany jest często bardzo ubogi" ${ }^{12}$. Z dotychczasowych ustaleń można natomiast stwierdzić, że zmiany, jakie zaszły w ewolucji hominidów, wydają się korespondować m.in. z pojemnością ich mózgoczaszki oraz z rozwojem zdolności umysłowych mózgu.

Współcześnie, co powtórzę, przyjmuje się, że około 100 tys. lat temu mózg Homo sapiens rozwinął się do obecnej wielkości (Tobias, 2008, s. 241-256), co może sugerować, że w pewnym czasie osiągnięto specyficzne, wyższe funkcje mózgu, których nie posiadały wcześniejsze hominidy (Kleibengajtis, 2012). Prawdopodobnie to właśnie wspomniany rozwój mózgu zaowocował nie tylko nowymi umiejętnościami, ale także nową formą samoświadomości związaną z poczuciem transcendencji (Suddendorf, Corbalis, 1997, s. 133-167). W kontekście tych transformacji nastąpiło przekroczenie progu symbolicznego - symbolic threshold (Deacon, 1997), co łączone jest z wkroczeniem w nowy etap tzw. „rozszerzonej świadomości” (Bickerton, 1995).

W opinii jednakże etnobotanika McKenna na rozwój ludzkiej świadomości mogły wpłynąć substancje psychogenne (pochodzące z roślin psychoaktywnych). Według tego badacza zaczątki szamanizmu mogły narodzić się jeszcze u hominidów poprzedzających czasy Homo sapiens i neandertalczyka (McKenna, 1992). Warto nadmienić, że nie tylko ludzie mogli doświadczać takich skutków spożywania roślin

11 Kompilację wyników współczesnych badań prowadzonych w tym paradygmacie przedstawił Thomas Kleibengajtis z Catolic Theology at University of Münster w pracy Human - a praying animal... (Kleibengajtis, 2012).

12 Poglądy Włodzisława Ducha zostały zamieszczone w publikacji internetowej: http://www.is.umk. pl/ duch/cog-book/A03evol.pdf [dostęp 15.04.2020] - (Duch, Umyst i ewolucja). 
psychoaktywnych, ale również zwierzęta, o czym świadczą wyniki badań przeprowadzonych (i ujętych w kompilacji) np. przez Giorgio Samorini (Samorini, 2002).

Niemniej u ludzi z tym zjawiskiem może korespondować m.in. wspomniane już doświadczanie odmiennych stanów świadomości - transu. Przy czym trans mógł być wywołany nie tylko przez przyjmowane substancje psychoaktywne, ale również wskutek niejako „naturalnego wejścia” w ,inną rzeczywistość”"13.

Powróćmy jednakże do pytania, czy tylko człowiek może przejawiać „zachowania zrytualizowane"? Należy podkreślić, że zazwyczaj są one przypisywane tylko człowiekowi i łączone $\mathrm{z}$ najwyższym stadium rozwoju hominidów ${ }^{14}$. $\mathrm{Z}$ dotychczasowych badań można ponadto wnosić, że „zachowania zrytualizowane" były obecne również u człowieka neandertalskiego (Langley, Clarkson, Ulm, 2014, s. 289-307; Burdukiewicz, 2014, s. 404), o czym świadczyła np. dbałość o zabezpieczenie ciał nieboszczyków (Pettitt, 2002, s. 1-19). Nadmienię, że w literaturze naukowej, w muzeach, a już zwłaszcza w kulturze popularnej długo jednak był utrwalany taki wizerunek neandertalczyka, który bardziej przypominał przedstawiciela prymarnych niż człowieka. Utrwalał się on od 1908 roku, gdy Marcellinie Boule, na podstawie odkrytych szczątków neandertalczyka w grocie La Chapelle-aux-Saints (z pomocą rysownika Frantiseka Kupki), zrekonstruował rzekomy jego wygląd (Boule, 1913).

We współczesnym świecie i rewolucyjnych wprost przemian nie jest wykluczone, że przyjdzie jednak nam się zmierzyć z próbą konieczności zweryfikowania kolejnej hipotezy, wedle której to nie tylko Homo sapiens czy Homo neanderthalis mógł wykazywać działania zrytualizowane, które odnosimy do wyższych uczuć, a nawet działań symbolicznych. W ten sposób wypowiedział się np. Jacques Derrida, który w ostatnich latach napisał:

wierzę - a stawka staje się coraz bardziej pilna - że żadna z umownie przyjętych granic między tak zwaną żywą istotą ludzką - i tak zwaną zwierzęcą, żadna z opozycji, żadna $\mathrm{z}$ rzekomo liniowych i niepodzielnych granic nie opiera się racjonalnej dekonstrukcji. (Derrida, 2005, s. 151)

W świetle współczesnych wyników badań publikacji zamieszczanych nawet w prestiżowych czasopismach naukowych coraz częściej podkreślany jest pogląd, że nie tylko te formy hominidów mogły być zdolne do zachowań zrytualizowanych, wykracza-

${ }^{13} \mathrm{~Np}$. pod wpływem rytmicznie powtarzających się dźwięków (bądź to słyszanych w naturze, bądź też intonowanych czy wywołanych przy pomocy bębnów itp.), ale także za sprawą monotonnych, długotrwale powtarzanych, rytmicznych ruchów.

${ }^{14}$ Przykładowo zdaniem Jeorga M. Nixona „ludzkie świadome doświadczenie pojawiło się nagle, w pewnym momencie, gdy doszło do takich przemian świadomości, które są unikalne i charakterystyczne tylko dla ludzi [...]. To wcale nie oznacza, że inne zwierzęta są automatami, ale że należy rozpoznać tę wielką przepaść oddzielającą doświadczenie i świadomość człowieka od zwierzęcego doświadczenia" (Nixon, 2010, s. 295). 
jących poza sfery instynktów ${ }^{15}$. Również wielu współczesnych etologów (co zostanie przedstawione poniżej) twierdzi, że przynajmniej u niektórych gatunków zwierząt takie kategorie zachowań są również obecne.

W tym kontekście należy też choć zaakcentować stosunek i sposoby percepcji zwierząt w dyskursach podejmowanych w nauce. Rozpocznijmy od poglądów Kartezjusza, który w XVII w. dowodził, że zwierzęta są automatami. Odmawiano im emocji, uczuć, myślenia - sprowadzając ich motywacje do mechanizmów, a z czasem m.in. do bodźców i instynktów (Pasieka, 2012, s. 51-64).

Przełom nastąpił w XX w., gdy tacy badacze jak np. Konrad Lorentz wskazywali i dowodzili, że takie poglądy są obciążone uproszczeniami. Wraz z rozwojem nauk pojawiły się pytania o zachowania intencjonalne, a nawet zastanawiano się, czy zwierzęta mają umysł (teoria umysłu np. w kontekście obserwowanych u prymarnych oszustw) (Dunbar, 2014). Konsternację w świecie nauki wzbudził również słynny eksperyment przeprowadzony z szympansami w niewoli (w 1977 roku), a opisany przez psychologa Gordona Gallupa. Jego wyniki udowodniły, że szympansy są zdolne do abstrakcyjnego myślenia ${ }^{16}$.

Jean Goodall poświęciła badaniom naczelnych (żyjącym na wolności) ponad pięćdziesiąt lat swego życia ${ }^{17}$. Udowodniła, że są to istoty społeczne, świadome, posiadające indywidualne charaktery, zdolne do empatii, procesu mentalizacji i komunikacji (według niej również - komunikacji symbolicznej ${ }^{18}$ ). Nadmienię, że w ostatnich latach kognitywiści i neurobiolodzy podkreślają, że system językowy, taki jak ludzki, czyli związany z artykułowaną mową, nie jest niezbędny dla rozwoju świadomości, choć niewątpliwie ją wzbogaca (Hofman, 2019, s. 266). Powracając zaś do badań prymatologów, także inni badacze wskazywali na wyjątkowe zdolności szympansów, a za przełomowe uważane są badania Kenziego - szympansa bonoboo (Savage-Rumbaugh, Lewin 1994). Zwrócono także uwagę na zachowania odnoszące się u prymarnych do postaw moralności (Kleibengajtis, 2012; Byrne, Whiten, 1992, s. 609-627). U zwierząt zaobserwowano również „zachowania protopogrzebowe” (King, 2008, s. 451-66), wskazujące na istnienie świadomości śmierci i poczucia straty członka stada, co dotyczy nie tylko prymarnych (Masson, McCarthy, 1995).

15 Przykładowo Jan Burdukiewicz podkreślał, że: „Niedawno stało się jasne, że kultura i symbole to nie tylko cechy ludzkie. Naukowcy, którzy wskazywali na obecność zachowań kulturowych u zwierząt, twierdzili, że kultura powinna być postrzegana przede wszystkim jako proces, a nie efekt lub - końcowy produkt. Takie procesy obserwuje się wśród wielu gatunków zwierząt, ale efekty są niewielkie pod względem ich ewolucji” (Burdukiewicz, 2014, s. 399).

16 Był to „eksperyment z lustrem i test czerwonej kropki”, który dowiódł, że badane prymarne były świadome swego - w lustrze - odbicia (Gallup, 1977, s. 329-338).

17 Godall prowadziła badania nad ich interakcjami społecznymi i rodzinnymi od 1960 roku (odkąd po raz pierwszy pojechała do Parku Narodowego Gombe Stream w Tanzanii).

18 Zjawisko to podkreślił m.in. Jan Burdukiewicz, wskazując na współczesne ujęcia semiotyki (rozumianej jako część logiki formalnej) w kontekście wykorzystania symboli w procesie komunikacji. Zaobserwowano bowiem, że np. afrykańskie małpy (Cercopithecus aethiops) spełniają definicję semiotycznego symbolu, używając określonych dźwięków wokalnych (Burdukiewicz, 2014, s. 399) (Ribeiroa, Loulabc, Araujoa, Gudwin, Queirozbd, 2007, s. 263-272). 
Goodall doszła nawet do wniosku, że skoro naczelne mają takie same jak ludzie emocje, nie jest wykluczone, że mogą mieć zdolność do przeżyć duchowych ${ }^{19}$. Zaobserwowała wyjątkowe zachowanie szympansów m.in. przy wodospadzie, rejestrując najpierw ich wzmożoną aktywność, poruszenie, a następnie specyficzne ruchy, które przypominały taniec, aż w końcu kontemplację osobników, którzy, siedząc naprzeciwko wodospadu, wpatrywali się w głębokim skupieniu w wodę $e^{20}$.

Zdaniem części badaczy poglądy Goodall są obciążone nadmierną emocjonalnością i antropomorfizacją zwierząt. Przykładowo Nancy Howell w tym kontekście napisała, że stwierdzenia Goodall są „dalekie od wystarczających dowodów niezbędnych do wykazania rozwoju «zachowań religijnych» czy duchowości istniejącej u szympansów" (Howell, 2003, s. 179-191). W perspektywie m.in. tych odkryć James B. Harrod zwrócił uwagę na potrzebę zrozumienia tego, co można ewentualnie uznać za duchowe/religijne, próbując nawet skonstruować pierwszą propozycję definicji duchowości/religii w ujęciu międzygatunkowym ${ }^{21}$.

\section{PODSUMOWANIE}

W świetle zasygnalizowanych jedynie zjawisk można stwierdzić, że na rozwój badań związanych z próbami poznania, zrozumienia i interpretowania „zachowań symbolicznych" zarówno u społeczności łowców-zbieraczy żyjących w paleolicie, jak i w czasach genezy rozwoju współczesnej nauki - duży wpływ miały nie tylko określone paradygmaty badawcze, ale także stereotypy, a nawet ideologie skutkujące m.in. uproszczeniami. Wraz z przekraczaniem ich granic nastąpił rozwój wiedzy. Miało to związek ze zmianami paradygmatów w nauce, $\mathrm{z}$ systematycznie prowadzonymi badaniami, rozszerzającą się wyobraźnią badawczą (m.in. za sprawą ujęć interdyscyplinarnych), dopracowywaną metodologią, z dostępem do coraz to bardziej wyrafinowanych narzędzi i technik badawczych.

W świetle współczesnych osiągnięć nauki wciąż jednak pozostaje nierozwiązany problem jednoznacznego wyjaśnienia np. genezy „zachowań symbolicznych”. Zazwyczaj przyjmuje się, że zmiany, jakie zaszły w ewolucji mózgu człowieka, miały miejsce około 100 tys. lat temu, co spowodowało różnice w rozwoju Homo sapiens, na tle innych hominidów. Z drugiej strony pojawiają się coraz częściej głosy m.in. etologów, sugerujące, że „,zachowania symboliczne” mogą być także domeną przynajmniej niektórych gatunków zwierząt, sugerując ich ciągłość. Te kwestie

\footnotetext{
${ }^{19}$ W podobny sposób wypowiadali się również inni prymatolodzy (Harrod, 2014, s. 8-45).

${ }^{20}$ Więcej informacji zamieszczono na stronie internetowej Jean Goodall Institute, Waterfall Displays, https://www.youtube.com/watch?v=jjQCZClpaaY (Goodall, 2005, s. 1303-1306).

${ }^{21}$ Badacz ten podjął się próby skonstruowania ogólnej definicji międzygatunkowej odnoszącej się do tej tematyki. Poddał analizie wszelkie obecne w anglojęzycznej literaturze definicje duchowości i religii, jak również związane z nimi denotacje i konotacje. Wykluczył z nich wszelkie odniesienia do antropocentryzmu, antropomorficzne projekcje, logocentryzm oraz to, co jest nieobserwowalne u innych gatunków, jak np. subiektywną mentalność (Harrod, 2011, s. 347).
} 
pozostają jednakże w kręgu hipotez i wymagają dalszych pogłębionych badań, mogących doprowadzić do ich weryfikacji. W tym kontekście, czerpiąc z myśli Marca Bekoffa, należy stwierdzić, że obecnie nie ma możliwości na zweryfikowanie hipotezy, wedle której przedstawiciele innych gatunków mogliby doświadczać „przeżyć religijnych” wskazujących na zalążki duchowego rozwoju zwierząt. „To, co wiemy o zdolnościach poznawczych i emocjonalnych szympansów i innych zwierząt sugeruje, że takie odkrycia, które mogą odnosić się do duchowości zwierząt, są na ten czas tylko hipotezami, które jednakże powinniśmy sprawdzić, a jednocześnie rozważyć, czy przedstawiciele innych gatunków mogą doświadczać przeżyć duchowych, posiadać rytuały przypominające te, które mogłyby leżeć u korzeni zachowań religijnych (Bekoff, 2007, s. 68-73). Coraz częściej akceptowany jest pogląd, że zwierzęta mogą mieć przynajmniej zalążki komunikacji symbolicznej, a wraz $\mathrm{z}$ innymi zjawiskami obserwowanymi w świecie zwierząt pojawiają się dalsze pytania o ewolucyjny charakter przemian odnoszących się do rozwoju człowieka (Laland, Janik 2006, s. 542-547).

\section{BIBLIOGRAFIA}

Balfour, $\mathrm{H}$.

1893 The Evolution of Decorative Art. An Essay upon its Origin and Development as Illustrated by the Art of Modern Races of Mankind. New York: Macmillan and Co.

Barański, E.

2010 Etnologia i okolice: Eseje antyperyferyjne. Kraków: Wydawnictwo Uniwersytetu Jagiellońskiego.

Berrocal, M. C.

2011 Analogical Evidence and Shamanism in Archaeological Interpretation. South African and European Palaeolithic Rock Art. Norwegian Archaeological Review, 44, 1-20.

Bickerton, D.

1995 Language and Human Behavior. Washington: University of Washington Press.

Blocker, H. G.

1994 The Aesthetics of Primitive Art. Lanham. University Press of America.

Boas, F.

1911 The Mind of Primitive Man. New York: Columbia University.

Boule, $\mathrm{M}$.

1913 L'homme fossile de la Chapelle-aux-Saints (extrait des Annales de paléontologie). Paris: Masson.

Boyer, $\mathrm{P}$.

2001 Religion Explained. The Evolutionary Origins of Religious Thought. London: Random House - New York: Perseus.

Boyer, P., Bergstrom, B.

2008 Evolutionary Perspectives on Religion. Annual Review of Anthropology, 37, 111-30.

Burdukiewicz, J. M.

2014 The origin of symbolic behavior of Middle Palaeolithic humans: Recentcontroversies. Quaternary International, 326-327, 398-405.

Byrne, R. W., Whiten, A.

1992 Cognitive evolution in primates. Man, 27, 609-627. 
Carlson, E. A.

2001 The Unfit: a history of a bad idea. Cold Spring Harbor. New York: Cold. Spring Harbor Laboratory Press.

Ciok, R.

2010 Przyczynowa teoria nazw Michaela Devitta. Rocznik Kognitywistyczny, 4, 43-49.

Conway, W. M.

1891 Dawn of Art in the Ancient World. An Archaeological Sketch. London: Percival.

Deacon, T. 1997

The Symbolic Species: The Co-Evolution of Language and the Brain. New York: W. W. Norton \& Co.

Derrida, J. 2005 Rogues: Two Essays on Reason. Stanford: Stanford University Press.

Duch, W. 2020

Umyst i ewolucja. Pobrano z: www.is.umk.pl/ duch/cog-book/A03evol.pdf

Dunbar, R. 2014 Nowa historia ewolucji człowieka (B. Kucharczyk, thum.). Kraków: Copernicus Center Press.

Duran, B., Duran, E.

2002 Native American Post-Colonial Psychology. New York: State University of New York.

Eliade, $\mathrm{M}$.

1988 Historia wierzeń i idei religijnych, t. 1: Od epoki kamiennej do misteriów eleuzyjskich

Frazer, J.

(S. Tokarski, thum.). Warszawa: Instytut Wydawniczy PAX.

1890 The Golden Bough: A Study in Magic and Religion. Oxford: Oxford University Press.

Fredrickson, G. M.

1988 The arrogance of race: historical perspectives on slavery, racism, and social inequality. Middletown: Conn Wesleyan University Press.

Gallup, G.

1977 Self recognition in primates: A comparative approach to the bidirectional properties of consciousness. American Psychologist, 32(5), 329-338.

Geertz, C.

2002 Religion as a cultural system. W: M. Lambeck (red.), A Reader in the Anthropology of Religion. Malden (s. 61-82). Oxford: MA: Blackwell Publishers Inc.

Goodall, J.

2005 „Primate spirituality”. W: B. Tylor (red.), The Encyclopaedia of Religion and Nature (s. 1303-1306). New York: Continuum.

2020 Jean Goodall Institute - Waterfall Displays. Pobrano z: www.youtube.com/watch?v=jjQCZClpaaY

Grosse, E.

1894 Die Anfänge der Kunst. Freiburg: Verlag: Mohr.

Grzelczyk, M.

2019 Archeologia ciągle żywa, czyli badania sztuki naskalnej wśród potomków jej twórców. Archeologia Żywa, 1(75), 20-25.

Haddon, A. 1895

Hanstrup, K.

2008 Droga do antropologii. Między doświadczeniem a teoria (E. Klekot, tłum.). Kraków:

Harrod, J. B.

Wydawnictwo Uniwersytetu Jagiellońskiego.

2011 A Trans-Species Definition of Religion. Journal for the Study of Religion Nature and Culture, 5(3), 327-353. 
2014 The Case for Chimpanzee Religion. Journal for the Study of Religion, Nature and Culture, $8(1), 8-45$.

Henshilwood, C. S., d'Errico, F. (red.)

2010 Homo Symbolicus: The Dawn of Language, Imagination and Spirituality. Amsterdam: University of Bergen.

Hirn, Y.

1900 The Origins of Art. A Psychological and Sociological Inquiry. London: Macmillan and Co.

Hoernes, M.

1909 Natur- und Urgeschichte des Menschen. Wien und Leipzig: A. Hartleben`s Verlag.

Hofman, M. A.

2019 On the nature and evolution of human mind. Progress in Brain Research, 250, 251-282.

Howell, N. R.

2003 The Importance of Being Chimpanzee. Theology and Science, 1(2), 179-191.

Kilijanek, M.

2009 Natura i kultura. W: T. Buksiński, E. Pakszys (red.), W Kręgu Filozofii Nauki, Kultury

i Spoleczeństwa (s. 171-196). Poznań: Wydawnictwo UAM.

King, B.

2008 Primates and Religion: A Biological Anthropologist's Response to J. Wentzel van Huyssteen's Alone in the World? Zygon, 43(2), 451-66.

Kleibengajtis, T.

2012 Human - a praying animal. Spirituality as consequence of brab evolution. GRIN Publishing.

Kulczycki, E.

2012 Teoretyzowanie komunikacji. Poznań: Wydawnictwo Naukowe Instytutu Filozofii UAM.

Laland, K. N., Janik, V. M.

2006 The animal cultures debate. Trends in Ecology and Evolution, 21(10), 542-547.

Langley, M. C., Clarkson, C., Ulm, S.

2014 Behavioural Complexity in Eurasian Neanderthal Populations: a Chronological Examination of the Archaeological Evidence. Cambridge Archaeological Journal, 18, 289-307.

Leroi-Gourhan, A.

1965 Préhistoire de l'art occidental. Paris: Éditions Mazenod.

1966 Religie prehistoryczne (I. Dewitz, thum.). Warszawa: Państwowe Wydawnictwo Naukowe. Lewis-Williams, J. D.

1981 Believing and Seeing. Symbolic Meanings in. Southern San Rock Paintings. London: Academic Press.

1991 Wrestling with analogy. A methodological dilemma in Upper Palaeolithic art research. Proceedings of the Prehistoric Society, 57(1), 149-162.

2006 The evolution of the-ory, method and technique in southern African rock art research. Journal of Archaeological Method and Theory, 13(4), 343-377.

2019 Sztuka naskalna ludu San: piękno I tajemnica. Archeologia Żywa, 1(75), 4-11.

Lewis-Williams, J. D., Dowson, T.

1988 Thesigns of all times. Entoptic phenomena in Upper Palaeolithic Art. Current Anthropolo-

Maruszewski, T. gy, 29(2), 201-244.

1996 Psychologia poznawcza. Warszawa: Wydawnictwo Znak-Język-Rzeczywistość.

Masson, M. J., McCarthy, S.

1995 When Elephants Weep: The Emotional Lives of Animals. New York: Delacorte.

McBrearty, S., Brooks, A. S.

2000 The Revolution that Wasn't: A New Interpretation of the Origin of Modern Human Behavior. Journal of Human Evolution, 39, 453-563. 
McKenna, T.

1992 Food of the Gods: The Search for the Original Tree of Knowledge, A Radical History of Plants, Drugs, and Human Evolution. New York: Bantam.

McLennan, J. M.

1869 The worship of animals and plants. Fortnightly Review, 6, 407-582.

Nixon, G. M.,

2010 Myth and Mind: The Origin of Human Consciousness in the Discovery of the Sacred.

Journal of Consciousness Exploration and Research, 1(3), 289-337.

Palacio-Pérez, E.

2010 Cave art and the theory of art: The origins of the religious interpretation of palaeolithic graphic expression. Oxford Journal of Archaeology, 29(1), 1-14.

Pasieka, P.

2012 Kartezjańska koncepcja zwierzęcia-maszyny. Filo-Sofija, 17(2), 51-64.

Pettitt, P. B.

2002 The Neanderthal Dead: Exploring Mortuary Variability. Middle Palaeolithic Eurasia, Before Farming, 1(4), 1-19.

Pütz, M., Verspoor, M. (red.)

2000 Explorations in Linguistic Relativity. Amsterdam - Philadelphia: John Benjamins Publishing.

Reinach, $\mathrm{S}$.

1899 Bibliographie. Paul Girop et Ėmile Massénat, Les stations de l'âge du Renne dans les vallées de la Vézère et de la Corrèze. Revue Archéologique, 35(3), 476-478.

1903 L'Art et la magie. L'Anthropologie, 14, 257-266.

Ribeiroa, S., Loulabc, A., Araújoa, I., Gudwin, R., Queirozbd, J.

2007 Symbols are not uniquely human. BioSytems, 90, 263-272.

Samorini, G.

2002 Animals and Psychedelics: The Natural World and the Instinct to Alter Consciousness.

Rochester - Vermont: Inner Traditions/Bear \& Company.

Sams, J., Nitsch, T. H.

1991 Other Council Fires Were Here Before Ours. San Francisco - California: Harper.

Sauvet, G., Layton, R., Lenssen-Erz, T., Taçon, P., Wlodarczyk, A.

2009 Thinking with Animals in Upper Palaeolithic Rock Art. Cambridge Archaeological Journal, 19(3), 319-336.

Savage-Rumbaugh, S., Lewin, R.

1994 Kanzi: The Ape at the Brink of the Human Mind. New York: John Wiley and Sons.

Saver, J., Rabin, J.

1997 The Neural Substrates of Religious Experience. Journal of Neuropsychiatry and Clinical Neurosciences, 9, 498-510.

Schiff, W. J., Moore, K.

2006 The impact of the sweat lodge ceremony on dimensions of well-being. Am Indian Alska Native Ment Health Research, 13(3), 48-69.

Stanner, W. E. H.

1966 On Aboriginal Religion (Oceania Monograph, 11). Sydney: University of Sydney.

Suddendorf, T., Corbalis, M. C.

1997 Mental Time Travel and the Evolution of the Human Mind. Genetic, Social, and General

Sutton, P. Psychology Monographs, 123(2), 133-167.

2009 The politics of suffering: Indigenous Australia and the end of the liberal consensus. Meulbourne: Melbourne University Press. 
Sztajer, S.

2012 Światopogląd religijny wobec nowego naturalizmu. O wybranych strategiach racjonalizacji religijnego obrazu Boga. W: Z. Drozdowicz, S. Sztajer (red.), Społeczno-kulturowe konteksty racjonalności (s. 95-106). Poznań: Wydawnictwo Naukowe UAM.

Szyjewski, A. 2008

Tobias, P. V.

2008 The promise and the peril in hominin brain. W: D. Falk, K. Gibson (red.), Evolutionary Anatomy of the Primate Cerebral Cortex (s. 241-256). Cambridge: Cambridge University Press.

Tylén, K., Fusaroli, R., Rojo, S., Heimann, K., Fay, N., Johannsen, N. N., Riede, F., Lombard, M.

2020 The evolution of early symbolic behavior in Homo sapiens. Proceedings of the National Academy of Sciences of the United States of America, 117(9), 4578-4584.

Tylor, E. B.

1867 Traces de la condition intellectuelle de l'homme dans les âges primitifs. Revue des tours scientifiques de la France et de l'étrangere, 45(4), 705-710.

Waldram, J. B.

1993 Aboriginal spirituality: symbolic healing in Canadian prisons. Cult Med Psychiatry, 17(3), 345-362.

Whitley, D. S.

2019 Sztuka naskalna Kalifornii. Archeologia Żywa, 1(75), 34-42.

Zaremba, M.

2011 Higieniści. Z dziejów eugeniki. Warszawa: Wydawnictwo Czarne.

\section{IN SEARCH OF THE BEGINNINGS AND TRIALS TO UNDERST AND "SYMBOLIC BEHAVIOR” OF THE PROBLEM}

\section{Sum mary}

Attempts to understand the content related to the so-called symbolic behavior (and consequently with the development of spirituality) create many research problems, which are intensified when we analyze, for example, the products of Palaeolithic artists. At the same time, the question of when the transition from sensory to the new world took place, associated with the development of the symbolic mind - linked to the crossing of the so-called symbolic threshold (Deacon, 1997), which can be associated with the beginning of the development of spirituality.

The aim of this article is an attempt to present the research on both the origins and the development of "symbolic behaviors" (McBrearty, Brooks, 2000, p. 453-563) and the ways of interpreting discoveries related to them. The phenomenon of difficulties in analyzing the products of, among others, Palaeolithic art, and in the historical perspective - the burdens resulting, among others, from the attitudes of ethnocentrism, or the consequences of the presence of negative stereotypes, referring both to Palaeolithic hunter-gatherers and to indigenous communities living in recent centuries, who have often been denied the right to perceive them in terms of people, has been stressed.

At the same time, the dominant view in science for a long time was that only Homo Sapiens was capable of developing spirituality and related ritual behaviors, which was gradually refuted 
with successive discoveries of the Neanderthal symbolic behavior. However, this did not affect the belief that the genesis of such great transformations should be sought primarily in the development of Homo Sapiens (although it was later admitted that Homo Neanderthalis was also capable of symbolic behavior and ritual activities related to them).

Nevertheless, attitudes to the artefacts of Paleolithic hunter-gatherers as well as to living indigenous communities have changed over time. Along with the development of research, there was also a sharp increase in spirituality, beliefs of indigenous communities.

Getting to know these contents made it possible to get closer to different ways of conceptualizing their world, and thanks to this, narratives and new research paradigms influencing the state of knowledge were also developed, among others, relating to attempts to understand the experiences of Palaeolithic artists.

In addition, in recent years, new hypotheses have emerged in the world of science, according to which the beginnings of ritualised behaviors - going beyond the sphere of drives and instincts should be sought in the animal world. 